\title{
Bezpieczna aborcja? Etyczne aspekty stosowania pigułki aborcyjnej RU-486
}

\author{
Andrzej Kobyliński \\ Wydział Filozofii Chrześcijańskiej, Uniwersytet Kardynała Stefana Wyszyńskiego \\ ul. Wóycickiego 1/3, 01-938 Warszawa, a.kobylinski@uksw.edu.pl
}

\section{Streszczenie}

Głównym celem artykułu jest analiza etycznych aspektów aborcji chemicznej, nazywanej również aborcją farmakologiczną lub medyczną. Aborcja chemiczna jest zwykle wykonywana przy użyciu dwóch preparatów. Pierwszym jest Mifepriston, znany także jako tabletka RU-486, a drugi to Mizoprostol. Preparaty są przyjmowane doustnie zasadniczo przez trzy dni, chociaż sama aborcja może potrwać znacznie dłużej. Mifepriston odpowiada za blokowanie działania kobiecego hormonu ciążowego progesteronu. Progesteron sprawia, że składniki odżywcze są dostępne w macicy dla nowo powstałego ludzkiego embrionu. Aborcja chemiczna nie tylko uśmierca nowe życie ludzkie na pierwszym etapie jego rozwoju, ale w niektórych przypadkach jest także niebezpieczna dla życia i zdrowia kobiet. Globalne zjawisko aborcji medycznej otwiera dziś nowy etap publicznego sporu o początek ludzkiego życia i uznanie ludzkiego zarodka jako istoty ludzkiej od momentu poczęcia.

\section{Słowa kluczowe}

etyka, bioetyka, pigułka aborcyjna RU-486, aborcja chemiczna, aborcja medyczna, ludzki embrion, polityka demograficzna, antykoncepcja awaryjna

\section{Wprowadzenie}

Jednym z największych dramatów moralnych współczesności jest ogromna liczba aborcji. Każdego roku wykonuje się ok. 56 milionów zabiegów aborcyjnych na całym świecie (por. Sedgh, Bearak 2016). Tylko na przestrzeni ostatnich dwudziestu lat dokonano na wszystkich kontynentach ok. jednego miliarda aborcji. Warto podkreślić, że te przerażające dane dotyczą zasadniczo aborcji chirurgicznej, ponieważ głównie taką formę przerywania ciąży uwzględnia się w raportach Międzynarodowej Organizacji Zdrowia. Trudno natomiast oszacować ogromną skalę aborcji chemicznej, która najczęściej jest pomijana w oficjalnych raportach krajowych i międzynarodowych.

Na przestrzeni ostatnich trzydziestu lat tradycyjna aborcja chirurgiczna jest coraz częściej zastępowana przez "nowoczesne” formy aborcji chemicznej, nazywanej także w niektórych krajach aborcją medyczną lub aborcją farmakologiczną. Aborcja przenosi się dzisiaj z sal operacyjnych, znajdujących się na szpitalnych oddziałach ginekologiczno-położniczych, do domów prywatnych oraz do aptek, punktów aptecznych czy Internetu, gdzie można kupić różnego rodzaju 
preparaty chemiczne, mające działanie aborcyjne. W konsekwencji tych głębokich zmian, dokonujących się na całym świecie, w niektórych krajach spada liczba aborcji chirurgicznych, natomiast gwałtownie wzrasta liczba aborcji chemicznych. Co więcej, metody aborcji medycznej są prezentowane w domenie publicznej jako bezpieczne dla życia i zdrowia kobiet. Rzekomo bezpieczna aborcja chemiczna zastępuje coraz częściej aborcję chirurgiczną.

Rewolucyjne zmiany w sposobie przeprowadzania aborcji spowodował preparat chemiczny o nazwie Mifepriston, znany najczęściej jako pigułka RU-486 albo tabletka „miesiąc później”. Stworzył go francuski naukowiec Étienne-Émile Baulieu w laboratorium Roussel Uclaf w Romainville w 1980 o. W kraju nad Sekwaną preparat został wprowadzony do aptek w $1988 \mathrm{r}$. Obecnie ta pigułka jest dopuszczona do obrotu w kilkudziesięciu krajach świata, m.in. w Australii, Chinach, Estonii, Finlandii, Francji, Hiszpanii, Indiach, Niemczech, Stanach Zjednoczonych, Szwecji, Wielkiej Brytanii.

Preparat stworzony przez francuskiego naukowca jest dzisiaj najbardziej znanym środkiem, wykorzystywanym do przeprowadzania aborcji chemicznej. W wielu państwach preparat chemiczny RU-486 jest oficjalnie nazywany pigułką aborcyjną (ang. abortion pill; niem. Abtreibungspille; wł. pillola abortiva). Rozwój Internetu sprawił, że tabletka „miesiąc później” jest w pewien sposób dostępna także w tych krajach, w których nie została oficjalnie dopuszczona do sprzedaży w aptekach. Polska należy do tych państw, w których tabletka „miesiąc później" nie została dopuszczona do obrotu, ale także mieszkańcy naszego kraju mogą ją kupić w innych państwach, gdzie jej stosowanie jest zgodne z obowiązującym prawem, bądź zamówić na portalach internetowych, które oferują sprzedaż wysyłkową tego preparatu chemicznego. Legalizacji pigułki aborcyjnej RU-486 w Polsce domaga się m.in. Federacja na Rzecz Kobiet i Planowania Rodziny oraz wiele innych środowisk politycznych i feministycznych.
Jak faktycznie działa pigułka aborcyjna RU-486? Kiedy zaczyna się życie ludzkie? W jaki sposób można dążyć dzisiaj do uznania ludzkiego embrionu jako bytu ludzkiego od momentu poczęcia? Jakie normy moralne powinny obowiązywać w świecie medycznym? Dokąd może nas zaprowadzić współczesna rewolucja bioetyczna i biotechnologiczna? Dlaczego Fundusz Ludnościowy Organizacji Narodów Zjednoczonych promuje i finansuje różne metody aborcji? Jak oceniać obecne podejście chrześcijan różnych denominacji do kwestii bioetycznych?

Głównym celem artykułu jest ukazanie najważniejszych aspektów etycznych stosowania pigułki aborcyjnej RU-486, a także nakreślenie szerszego kontekstu współczesnej dyskusji filozoficznej i bioetycznej, dotyczącej początku życia ludzkiego i możliwości ochrony podstawowych praw ludzkiego embrionu na pierwszym etapie jego rozwoju.

\section{Specyfika działania tabletki RU-486}

Preparat Mifepriston, nazywany pigułką aborcyjną RU-486, jest związkiem chemicznym z grupy steroidów. Stanowi pochodną noretysteronu i jest wytwarzany syntetycznie. Mifepriston odpowiada za blokowanie działania kobiecego hormonu ciążowego progesteronu i zatrzymanie procesu rozwoju ludzkiego embrionu. Preparat blokuje działanie progesteronu poprzez zablokowanie receptora progesteronowego - progesteron nie działa bez receptora, działa tylko przez receptor. Jak zatem wygląda aborcja chemiczna z zastosowaniem tabletki „miesiąc później”? Aborcja farmakologiczna jest metodą stosowaną tylko we wczesnym okresie ciąży, tj. do 7-8 tygodnia. Pierwszy etap polega na przyjęciu tabletki RU-486, która zawiera 200, 400 lub 600 mg Mifepristonu. Zastosowanie tego środka aborcyjnego prowadzi do zahamowania rozwoju ciąży. Preparat powoduje uśmiercenie nowo powstałego życia w łonie matki. W 3-5\% przypadków dochodzi do jednoczesnego wydalenia z organizmu kobiety martwego ludzkiego embrionu. 
Drugi etap aborcji chemicznej polega na zastosowaniu preparatu o nazwie Mizoprostol. Czym jest ten środek medyczny? To syntetyczny analog prostaglandyny E1, stosowany także w wielu krajach jako lek w prewencji i leczeniu choroby wrzodowej żołądka. Mizoprostol jest produkowany m.in. przez amerykański koncern farmaceutyczny Pfizer/Pharmacia pod nazwą handlową Cytotec. Jeśli po przyjęciu pigułki „miesiąc później" nie doszło do wydalenia ludzkiego embrionu, to po trzech dniach od momentu zastosowania RU-486 kobieta powinna przyjąć tabletkę zawierającą 400 mcg Mizoprostolu, który w 80\% przypadków powoduje usunięcie uśmierconego poczętego dziecka $\mathrm{z}$ organizmu matki.

Jak działa ten preparat? Mizoprostol wywołuje skurcze macicy, które sprawiają wydalenie martwego embrionu (por. Morresi, Roccella 2010). Po dwóch tygodniach od przyjęcia Mizoprostolu wskazana jest wizyta u ginekologa, aby sprawdzić, czy w macicy nie ma żadnych szczątków martwego embrionu. Z badań prowadzonych w niektórych krajach wynika, że 5-8\% kobiet, które dokonały aborcji chemicznej, musi poddać się dodatkowo także zabiegowi chirurgicznemu abrazji jamy macicy, którego celem jest usunięcie znajdujących się tam szczątków embrionalnych (por. Flamingi, Melega 2010).

Działanie tabletki RU-486 ma charakter typowo aborcyjny. Warto w tym miejscu dodać, że w przypadku tego preparatu nie ma kontrowersji dotyczących antykoncepcji postkoitalnej lub tzw. antykoncepcji awaryjnej. Chodzi tutaj szczególnie o pigułki „dzień później” i „pięć dni później”, które mogą mieć działanie zarówno antykoncepcyjne, jak i aborcyjne. Dlaczego? Preparaty antykoncepcji postkoitalnej działają jako środki antykoncepcyjne tylko wtedy, gdy ich przyjęcie ma miejsce kilka dni przed owulacją. W tej sytuacji blokują one proces owulacji. Tylko i wyłącznie w tym przypadku działanie tych tabletek wywołuje skutki antykoncepcyjne. Działanie antyowulacyjne ma charakter antykoncepcyjny. Gdy tzw. antykoncepcja awaryjna jest stosowana już po tym, gdy nastąpiło połączenie męskiej komórki rozrodczej z komórką jajową, jej działanie ma charakter stricte antyimplantacyjny, czyli aborcyjny (por. Cavoni, Sacchini 2008).

Na skutki antyimplantacyjne antykoncepcji postkoitalnej zwraca uwage od wielu lat m.in. amerykańska Agencja Żywności i Leków (FDA - Food and Drug Administration). Niestety, wiele środowisk politycznych i medialnych wywiera ogromną presję na FDA wzywa się Agencję do usunięcia z ulotek informacji, zawierających sugestię, że tabletki antykoncepcji postkoitalnej zaburzają czy też uniemożliwiają implantację. Tego rodzaju wątpliwości nie ma w przypadku preparatu RU-486. Nikt nie neguje bezspornego faktu medycznego, że pigułka „miesiąc później" ma typowe działanie aborcyjne. Jeśli ten preparat medyczny jest stosowany w 7-8 tygodniu ciąży, to uśmiercane nienarodzone dziecko ma już bijące serce oraz funkcjonujący mózg. Pojawiają się też u takiego dziecka pierwsze odruchy nerwowe, tworzą się mięśnie i szkielet.

Warto także pamiętać o tym, że w niektórych przypadkach stosowanie tabletki „miesiąc później” może być także niebezpieczne dla zdrowia i życia przyjmującej ten preparat kobiety. Preparat Mifepriston nie tylko uśmierca nowe życie ludzkie na pierwszym etapie jego rozwoju, ale w niektórych przypadkach jest także niebezpieczny dla życia i zdrowia kobiet. W 2017 r. oficjalne dane mówiły o 29 zgonach matek w różnych krajach, wywołanych przyjęciem pigułki RU486. Tego rodzaju statystyki są prowadzone jedynie w państwach zachodnich. Dlatego trudno stwierdzić, jaka może być faktyczna liczba takich zgonów np. w Indiach czy w Chinach, gdzie preparat jest stosowany przez miliony kobiet.

\section{Kiedy zaczyna się życie ludzkie?}

W ocenie moralnej stosowania pigułki „miesiąc później" kluczowe znaczenia ma kwestia początku życia ludzkiego. Warto podkreślić, że pytanie o początek życia człowieka oraz kwestia statusu wczesnego etapu rozwoju 
ludzkiego embrionu stanowią od wielu lat jedno „z najintensywniej dyskutowanych zagadnień bioetycznych" (Machinek 2005: 136). Niezwykle inspirująca debata na ten temat miała miejsce m.in. we Włoszech, w kontekście ogólnonarodowego referendum na temat stosowania technik rozrodu wspomaganego, jakie zostało przeprowadzone w czerwcu 2005 r. Po referendum szczególnie ważnym zjawiskiem okazała się bardzo ciekawa dyskusja na temat statusu ludzkiego embrionu, która toczyła się w kraju nad Tybrem przez kilka miesięcy na łamach wielu gazet i czasopism.

Ogólnonarodowa debata publiczna ukazała ograniczenia współczesnej refleksji filozoficznej na temat statusu embrionu i definicji życia ludzkiego. Pytania dotyczące początku i istoty człowieczeństwa powróciły po referendum ze zdwojoną siłą. W dyskusji zabrali głos najważniejsi włoscy filozofowie i intelektualiści. Zwolennicy referendum (m.in. M. Cacciari, S. Givone, E. Severino, G. Vattimo, S. Veca), domagający się liberalizacji włoskiego prawa dotyczącego stosowania metody in vitro, zwrócili uwagę szczególnie na to, że ludzki embrion nie ma takich samych praw jak osoba dorosła, natomiast obrońcy konserwatywnej ustawy o sztucznym zapłodnieniu z 2004 r. (m.in. D. Antiseri, E. Berti, F. Botturi, V. Possenti, C. Vigna) „podkreślili przede wszystkim osobowy charakter dziecka poczętego" (Kobyliński 2007: 166).

Stwierdzenia biologów, genetyków czy mikrobiologów odpowiadają potocznemu przeświadczeniu, że życie każdej istoty ludzkiej zaczyna się w momencie jej poczęcia. Z biologicznego punktu widzenia rozwój zygoty od początku odznacza się trzema właściwościami: koordynacją, ciągłością i stopniowością. Biologiczne zindywidualizowanie istot żywych oznacza przede wszystkim ich organiczną jedność, zdolną do istnienia jako odrębny byt (por. Sgreccia 1996: 103-152). Indywidualizacja zygoty ludzkiej stanowi początek życia nowej jednostki (por. Ślipko 2009: 119-150). Nauka potwierdza biologiczną indywidualizację zygoty od momentu jej poczęcia. Skoro jest bytem ludzkim, to jest także podmiotem praw (por. Gormally 2004).

Chrześcijańska etyka personalistyczna uznaje osobowy status ludzkiego embrionu od pierwszej chwili jego istnienia. Nie podziela tego stanowiska wiele współczesnych światopoglądów, religii, kościołów i związków wyznaniowych, nurtów filozoficznych czy prądów politycznych, które traktują embrion jako człowieka w sensie potencjalnym, mówią o zarodku jako mikroskopijnym bycie ludzkim czy też nazywają zygotę preembrionem, a nie nowym bytem ludzkim. W ten sposób dochodzi do zafałszowania prawdziwej natury i tożsamości ludzkiego embrionu (por. Puccetti 2008).

Przedstawiciele chrześcijańskiej etyki personalistycznej zwracają uwagę na to, że oczywiście osobowość embrionu empirycznie i fenomenologicznie przejawia się w inny sposób niż osobowość człowieka narodzonego, niemniej jednak ukazuje się w sposób właściwy istocie przynależącej do rodzaju ludzkiego. „Rozwój nauk przyrodniczych stwierdza Ryszard Otowicz - dostarczył nowych przesłanek empirycznych, które pozwalają na prowadzenie refleksji nad początkiem ludzkiego życia w świetle faktów biologicznych" (Otowicz 1998: 147). Gdy komórka jajowa ulega zapłodnieniu, rozpoczyna się życie, które nie należy już ani do ojca, ani do matki, ale do nowej, żyjącej istoty ludzkiej, która rozwija się dla siebie samej. Proces zapłodnienia jest pewnym continuum bez żadnych "przeskoków jakościowych” i podziałów w czasie.

W sporze o początek życia ludzkiego powinno być rozstrzygające przede wszystkim kryterium genetyczne. W chwili poczęcia nowy byt rozpoczyna natychmiast swój własny cykl życiowy. Kod genetyczny determinuje jedność kierunku rozwojowego i gwarantuje trwałą jedność podmiotu określa nie tylko przynależność embrionu do rodzaju ludzkiego, ale także specyficzne cechy i indywidualne właściwości rozwijającej się istoty. Pytanie o moment pojawienia się zindywidualizowanego podmiotu życia 
ludzkiego „należy wiązać z kodem genetycznym, a nie ze stopniem rozwoju cielesnego organu, mającego być materialnym podłożem dla określonej, typowo ludzkiej, władzy duchowej czy też określonej struktury anatomicznej zarodka" (Otowicz 1998: 178).

Opierając się na faktach naukowych, potwierdzonych m.in. przez embriologię czy genetykę, należy uznać, że embrion ludzki jest podmiotem praw osobowych: prawa do narodzenia się, prawa do uznania własnego statusu osobowego, prawa do wolności egzystencjalnej, prawa do integralności fizycznej i genetycznej, prawa do zdrowia, prawa do nietykalności natury biologicznej, prawa do godnej śmierci.

Światowej sławy francuski genetyk Jérôme Jean Lejeune (1926-1994) twierdził, że w naszych czasach - dzięki nadzwyczajnemu postępowi techniki - wtargnęliśmy do prywatnego życia płodu. Przyjęcie za pewnik faktu, że po zapłodnieniu powstała nowa istota ludzka, nie jest już sprawą upodobań czy opinii. Ludzka natura tej istoty od chwili poczęcia do starości nie jest metafizycznym twierdzeniem, z którym można się spierać, ale zwykłym faktem doświadczalnym. Lejeune uważał, że zapłodnienie jest przekazaniem informacji genetycznej cząsteczkom materialnym, swego rodzaju niematerialnej więzi łączącej cały nowy organizm. Nazywał to "zleceniem genetycznym” w stosunku do materii. W „zleceniach” wpisanych w struktury fizyczne kodu genetycznego najważniejsza jest struktura znaczeniowa - transfer pewnej charakterystycznej struktury zakodowanych makrocząsteczek, który jest jedynym stałym i niezmiennym transferem z pokolenia na pokolenie (por. Lejeune 2005).

Wydaje się, że reasumując kwestie związane z początkiem życia ludzkiego, można wskazać cztery najważniejsze argumenty o charakterze racjonalnym, które potwierdzają człowieczeństwo ludzkiego embrionu od momentu poczęcia i bronią jego charakteru osobowego (por. Machinek 2005: 137-142).
Po pierwsze, argument przynależności gatunkowej. Każdy ludzki zarodek jest tożsamy genetycznie z gatunkiem homo sapiens, przynależy do tego gatunku i jest jednym z jego reprezentantów. Oznacza to także uczestnictwo embrionu w godności ludzkiej, którą posiada każdy przedstawiciel gatunku homo sapiens.

Po drugie, argument ciągłości rozwojowej. Nie ma żadnego kryterium umożliwiającego wyróżnienie w rozwoju prenatalnym fazy ludzkiej i przedludzkiej. Nie możemy wskazać żadnego punktu zwrotnego - poza momentem poczęcia - w którym de facto życie embrionalne staje się życiem ludzkim. Po zapłodnieniu nie można wskazać na inny fakt stanowiący o hominizacji zarodka. To oznacza, że rozwój istoty ludzkiej jest ciągły - na żadnym etapie rozwoju nie występuje jakikolwiek „skok jakościowy”

Po trzecie, argument tożsamości indywidualnej. Istota ludzka zachowuje tożsamość indywidualną przez całe swoje życie - od momentu poczęcia aż po kres śmierci. Przez cały czas mamy do czynienia z tą samą osobą.

Po czwarte, argument potencjalności. W przypadku człowieka potencjalność oznacza biologiczną możliwość rozwoju. Jeśli zagwarantujemy odpowiednie warunki, każdy ludzki zarodek ujawni wszystkie cechy właściwe osobie ludzkiej.

\section{Polityka demograficzna Funduszu Ludnościowego ONZ}

Od 2011 r. Organizacja Narodów Zjednoczonych próbuje narzucić całemu światu globalny podatek, służący finansowaniu różnych form aborcji w wielu regionach naszej planety (por. Web-01). Inicjatywa budząca sprzeciw moralny niektórych środowisk nawiązuje m.in. do decyzji podjętych w trakcie Międzynarodowej Konferencji nt. Zaludnienia i Rozwoju, która odbyła się w dniach 5-13 września 1994 r. w Kairze. Głównym celem konferencji było uzgodnienie działań międzynarodowych na rzecz zahamowania przyrostu naturalnego w krajach rozwijających się, skupiając się na tzw. zdrowiu 
reprodukcyjnym i kładąc nacisk na umożliwienie kobietom kontrolowania własnej płodności. Organizatorzy konferencji byli przekonani, że jeśli kobiety chcą mieć mniej dzieci niż ich matki, wystarczy im zapewnić środki medyczne do kontroli płodności, a zostanie zamknięty w ten sposób problem przeludnienia i kurczenia się zasobów naturalnych naszej planety (por. Kobyliński 2015: 20-24).

Dla przedstawicieli różnych agend ONZ jedną z bardzo skutecznych metod kontroli urodzeń jest aborcja chemiczna. Urzędnicy ONZ przekonują, że źródłem finansowania preparatów aborcji medycznej powinien być specjalny podatek, który jest obecnie częścią szerokiego planu rozwoju zrównoważonego, jaki został przygotowany w siedzibie tej organizacji w Nowym Jorku na lata 2015-2030. Jest to jeden z najważniejszych, ale jednocześnie najbardziej niebezpiecznych dokumentów o charakterze globalnym. Opracowanie przygotowane przez urzędników ONZ było przedmiotem dyskusji m.in. podczas World Humanitarian Summit w Istanbule w maju $2016 \mathrm{r}$.

Jaki jest podstawowy cel programu zawartego w tym dokumencie? Najważniejsza propozycja dotyczy tego, żeby decyzję o finansowaniu różnych form aborcji odebrać demokratycznej woli obywateli poszczególnych krajów członkowskich ONZ. Zgodnie z tym projektem, takie decyzje powinni podejmować samodzielnie urzędnicy ONZ, a nie rządy czy parlamenty poszczególnych krajów. W ten sposób pracownicy ONZ mieliby pełną kontrolę nad tym, w jaki sposób są wydawane pieniądze przeznaczone na politykę kontroli urodzeń. Skąd powinny pochodzić środki finansowe? Proponowany przez ONZ podatek dotyczyłby niektórych transakcji finansowych, dokonywanych przez konsumentów przy zakupie biletów lotniczych czy przy wymianie waluty.

Jedną z najważniejszych organizacji międzynarodowych, która ma duży wpływ na kształtowanie polityki kontroli urodzeń i promocję aborcji jest Fundusz Ludnościowy Narodów Zjednoczonych (United Nations
Population Fund - UNFPA). Warto w tym miejscu podkreślić, że Fundusz powstał w 1969 r. jako Fundusz Narodów Zjednoczonych na rzecz Działań Ludnościowych (UNFPA). W 1987 r. zmieniono jego nazwę na obecną, ale pozostawiono znany już na świecie skrót. UNFPA prowadzi działania związane z szeroko rozumianą sferą praw kobiet, świadomego rodzicielstwa, poprawy warunków rodzenia oraz walki z chorobami przenoszonymi drogą płciową. Najważniejszymi dziedzinami, w których Fundusz prowadzi i finansuje projekty w ok. 140 państwach, są takie obszary jak planowanie rodziny i zapobieganie tzw. niechcianym ciążom, ograniczanie liczby zarażeń chorobami przenoszonymi drogą płciową (w szczególności HIV/AIDS), zwalczanie przemocy rodzinnej, promocja równouprawnienia kobiet itp.

Jesienią 2016 r. Fundusz Ludnościowy poddał ocenie własny dokument dotyczący planowania rodziny na lata 2008-2013. Ocena miała charakter pewnego bilansu, którego celem było ustalenie, w jakim stopniu jest skuteczna dotychczasowa polityka kontroli urodzeń, prowadzona przez różne agendy Organizacji Narodów Zjednoczonych (por. Web-02). Warto zauważyć, że w tej materii ONZ odwołuje się do statystycznej teorii zasobów, której twórcą był angielski duchowny i ekonomista Thomas Malthus (1766-1834), prowadzący badania z pogranicza ekonomii i socjologii. Według tego myśliciela, skoro liczba ludności rośnie w postępie geometrycznym, a produkcja żywności - w arytmetycznym, to nieunikniony jest stan przeludnienia. Analizy prowadzone w 2016 r. przez Fundusz Ludnościowy miały także na celu nakreślenie kierunku działań na najbliższych kilkanaście lat. Plany dotyczące przyszłości zawierają m.in. globalny program poprawy zdrowia reprodukcyjnego kobiet, w którym chodzi także o promocję praktyk aborcyjnych, antykoncepcję i sterylizację.

Przedstawiciele UNFPA wyrazili satysfakcję z tego powodu, że w niektórych krajach rozwijających się funkcjonuje tzw. metoda mieszana kontroli urodzeń - triada 
aborcji, antykoncepcji i testu ciążowego. Inne metody to pigułki aborcyjne, implanty podskórne, preparaty tzw. antykoncepcji awaryjnej - pigułki „dzień później” i „pięć dni później”. Po analizie dokonanej jesienią 2016 r. stwierdzono, że środki kontroli urodzeń dotychczas stosowane są niewystarczające. W konsekwencji należy zwiększyć zakres wykorzystywania pigułki aborcyjnej RU-486. Zamiarem Funduszu Ludnościowego jest nakłonienie rządów całego świata, aby wpisały ten preparat aborcyjny na listę leków podstawowych. Warto w tym miejscu dodać, że w niektórych krajach ten cel został już osiągnięty. Zgodnie z planami Funduszu Ludnościowego ONZ, w najbliższych latach pigułka RU-486 stanie się najważniejszym narzędziem ogólnoświatowej polityki kontroli urodzeń.

Gdy chodzi o Mizoprostol, jest on zasadniczo dostępny w aptekach, ponieważ może być wykorzystywany m.in. podczas leczenia krwotoków poporodowych, choroby wrzodowej żołądka lub osłonowo/zapobiegawczo przy stosowaniu niesteroidowych leków przeciwzapalnych. Działaniem niepożądanym tego preparatu są skurcze macicy, które mogą doprowadzić do przerwania ciąży. Wydaje się, że plan Funduszu Ludnościowego jest następujący: w tych krajach, gdzie Mifepriston jest zakazany, należy ułatwić dostęp do preparatu Mizoprostol pod pretekstem, że jest to lek przydatny np. przy powikłaniach poporodowych. W ten sposób organizacje pozarządowe, promujące różne formy aborcji w krajach Afryki czy Azji, będą mogły doradzać kobietom, jak doprowadzić samodzielnie do przerwania ciąży i jak następnie zastosować Mizoprostol, aby usunąć abortowany płód z łona matki.

Zastosowanie tego preparatu może także prowadzić do aborcji w sposób bardziej bezpośredni. W jakich okolicznościach? Jeśli ten produkt medyczny jest przyjęty przez kobietę przed 12. tygodniem ciąży, może spowodować bezpośrednio śmierć dziecka poczętego poprzez wywołanie porodu i wydalenie płodu poza organizm matki. Także po przekroczeniu tej granicy czasowej skutki działania Mizoprostolu mogą mieć charakter aborcyjny, ale zwiększa się wówczas stopień zagrożenia dla życia i zdrowia kobiety. Fundusz Ludnościowy przekonuje w swoich dokumentach oraz w różnego rodzaju działaniach lobbystycznych, że stosowanie tego preparatu medycznego rzekomo chroni matki przed poddawaniem się niebezpiecznym formom aborcji chirurgicznej.

Żeby uzyskać akceptację poszczególnych krajów dla globalnego dostępu do Mizoprostolu, UNFPA ukrywa jego działanie aborcyjne i nie informuje o negatywnych skutkach tego preparatu dla życia i zdrowia kobiet. Ewentualne wpisanie tego środka na listę leków podstawowych wiąże się także z jego finansowaniem przez systemy opieki zdrowotnej poszczególnych państw. Władze rządowe niektórych krajów uznały "dyskretne" przywództwo Funduszu Ludnościowego w kampanii promocyjnej Mizoprostolu i umieściły ten preparat na listach leków podstawowych. Zdaniem urzędników UNFPA, takie decyzje - podjęte we wszystkich krajach świata - mogą zrewolucjonizować dostęp do tzw. bezpiecznej aborcji, czyli do różnych form aborcji chemicznej.

Propozycji Funduszu Ludnościowego nie akceptuje m.in. administracja amerykańskiego prezydenta Donalda Trumpa. Na początku 2017 r. nowe władze USA wykazały zdecydowanie większą wrażliwość moralną w kwestii aborcji niż administracja Baracka Obamy. Jedna z pierwszych decyzji, podjętych przez 45. prezydenta Stanów Zjednoczonych, dotyczyła przerwania finansowania przez USA organizacji pozarządowych, promujących w świecie aborcję - szczególnie w biednych krajach Afryki i Azji. Administracja Donalda Trumpa przestała także wspierać finansowo Fundusz Ludnościowy ONZ, który zajmuje się kontrolą urodzeń na całym świecie, szczególnie w krajach biednych i zapóźnionych cywilizacyjnie. Niestety, Fundusz Ludnościowy popiera i promuje m.in. programy rządowe Chińskiej Republiki Ludowej, które przewidują aborcję przymusową i zmuszanie kobiet do poddania się sterylizacji. W 1980 r. w Państwie Środka 
wprowadzono politykę jednego dziecka. Od tego czasu dokonano w tym kraju ok. 400 milionów aborcji - wykorzystując w tym celu także fundusze ONZ.

Warto w tym miejscu dodać, że tylko w 2016 r. administracja Baracka Obamy przekazała na działalność Funduszu Ludnościowego ONZ 68 milionów dolarów. Od 2017 r. - po decyzji prezydenta Donalda Trumpa - te środki będą przeznaczone na politykę społeczną i programy pomocowe w różnych zakątkach świata. Wdzięczność wobec prezydenta Donalda Trumpa za podjęcie tego rodzaju decyzji wyraziła m.in. Konferencja Episkopatu Stanów Zjednoczonych, określając takie działania jako „wielkie zwycięstwo kobiet i dzieci całego świata”.

Niestety, całkowicie odmienne podejście w kwestii aborcji dominuje w Unii Europejskiej. Na początku 2017 r. przedstawiciele Komisji Europejskiej zapowiedzieli, że udzielą pomocy finansowej tym organizacjom pozarządowym, które zostały pozbawione środków pieniężnych przez prezydenta Donalda Trumpa. Oznacza to w praktyce, że w najbliższych latach najprawdopodobniej wszyscy podatnicy Unii Europejskiej, w tym także mieszkańcy Polski, będą finansować nieetyczne działania wielu organizacji pozarządowych i Funduszu Ludnościowego, które w 2017 r. przestali wspierać obywatele Stanów Zjednoczonych.

\section{Moralne meandry współczesnego katolicyzmu}

Poważny spór etyczny, dotyczący stosowania pigułki RU-486 i preparatów antykoncepcji postkoitalnej, łączy się dzisiaj z głęboką transformacją, jakiej w ostatnich latach podlega katolicyzm w Europie i na całym świecie. Na początku 2017 r. ukazała się we Włoszech bardzo ciekawa praca zbiorowa pt. Bioetyka katolicka i bioetyka laicka w epoce papieża Franciszka. Co się zmienito? Redaktorem naukowym tego opracowania jest Luca Lo Sapio z Uniwersytetu Neapolitańskiego im. Fryderyka II w Neapolu (por. Lo Sapio 2017). Autorzy tej publikacji zwrócili uwagę na rewolucyjne zmiany, dotyczące kwestii moralnych, jakie wprowadza od 2013 r. papież Franciszek.

Gdy chodzi o bioetykę katolicką i bioetykę laicką, oczywiście nie ma mowy o zakwestionowaniu różnic istniejących między tymi dwoma paradygmatami moralnymi. Autorzy twierdzą, że nie wszystko się zmieniło, ale też nie wszystko zostało tak jak było wcześniej. Nowa perspektywa katolicka jest ukierunkowana na dialog: szukać bardziej tego, co łączy, a nie tego, co dzieli. Papież Franciszek o wiele rzadziej porusza tematy bioetyczne niż jego poprzednicy. Kładzie akcent na inne zagadnienia etyczne dotyczące ubóstwa, ochrony środowiska, migracji, dyskryminacji, niesprawiedliwości społecznej. W konsekwencji bioetyka zeszła na dalszy plan. Liczą się nie tyle kwestie doktrynalne, ile duszpasterskie.

Autorzy opracowania pokazują zmianę argumentacji moralnej prezentowanej ostatnio przez środowiska katolickie - główną rolę zaczyna odgrywać nie tyle moralność ugruntowana na prawie naturalnym, ile moralność publiczna. Ten proces powoduje osłabienie społecznej obecności katolików. Jeszcze kilka lat temu np. we Włoszech toczyły się wielkie debaty światopoglądowe dotyczące sztucznego zapłodnienia, aborcji chemicznej czy antykoncepcji postkoitalnej. Ważnym uczestnikiem tej dyskusji były także środowiska katolickie. Bardzo często w domenie publicznej pojawiały się odwołania do dokumentów kościelnych, mających kluczowe znaczenie doktrynalne dla refleksji bioetycznej. Wystarczy wspomnieć dwie encykliki Jana Pawła II: Veritatis splendor z 1993 r. i Evangelium vitae z 1995 r., a także Instrukcję Kongregacji Nauki Wiary z 2008 r. Dignitas personae, zaaprobowaną przez papieża Benedykta XVI. Obecnie w kraju nad Tybrem głos katolików w kwestiach bioetycznych jest prawie niesłyszalny - coraz częściej dominuje obojętność, bezradność i milcząca akceptacja dla dokonującej się na naszych oczach głębokiej rewolucji moralnej. Tego rodzaju pasywna postawa środowisk katolickich w wielu krajach dotyczy m.in. stosowania pigułki aborcyjnej RU-486. 
$\mathrm{Na}$ przełomie marca i kwietnia $2017 \mathrm{r}$. wiele mediów na świecie komentowało bulwersujący przypadek dotyczący Katolickiego Uniwersytetu Lowańskiego w Belgii. Stéphane Mercier - filozof, profesor wizytujący tej uczelni - został odsunięty od nauczania i wszczęto w jego sprawie postępowanie dyscyplinarne (por. Del Re 2017). Dlaczego? Podczas zajęć ze studentami nazwał aborcję zabójstwem. W oficjalnym komunikacie władze uczelni stwierdziły, że tego rodzaju opinia jest niezgodna z wartościami wyznawanymi przez Katolicki Uniwersytet Lowański. Jako wartości podstawowe wskazano w oświadczeniu otwartość na innych i na odmienność, solidarność, wolność i szacunek.

Niestety, także władze Kościoła katolickiego w Belgii nie udzieliły wsparcia temu profesorowi. Rzecznik prasowy Konferencji Episkopatu Belgii, Tommy Schoitès, stwierdził, że słowa prof. Merciera są karykaturalne. Zdaniem rzecznika prasowego, słowo "zabójstwo" w odniesieniu do aborcji jest zbyt mocne. Biskupi frankofońscy Belgii potwierdzili w specjalnym komunikacie, że mają pełne zaufanie do wewnętrznych procedur stosowanych przez Katolicki Uniwersytet Lowański.

Stéphane Mercier zaklasyfikował etycznie aborcję jako zabójstwo niewinnej jednostki ludzkiej. Władze Katolickiego Uniwersytetu Lowańskiego uznały, że skoro możliwość aborcji jest wpisana od wielu lat do belgijskiego systemu prawnego, to należy odrzucić poglądy prezentowane przez Merciera i uznać je za sprzeczne z wartościami i misją uczelni (por. Colombo 2017). Co zatem z wolnością badań naukowych w świecie uniwersyteckim? Na czym polega katolickie nauczanie moralne? Jak rozumieć w tym kontekście wolność sumienia i religii? Przypadek Katolickiego Uniwersytetu Lowańskiego pokazuje nam bardzo wyraźnie, jak głębokim zmianom podlega dzisiaj katolicyzm w Europie i na całym świecie. W konsekwencji tych zmian, przedstawiciele środowisk katolickich podejmują coraz rzadziej m.in. moralny problem aborcji chirurgicznej i chemicznej.

\section{Podsumowanie}

W ostatnich latach przetacza się przez naszą planetę tzw. rewolucja holenderska, która polega przede wszystkim na dopasowywaniu prawa stanowionego do niezwykle głębokich przemian o charakterze moralnym, jakie dokonały się w wielu krajach w wyniku m.in. rewolucji obyczajowej $1968 \mathrm{r}$. Jednym z przejawów tego procesu jest legalne stosowanie preparatu medycznego RU-486 oraz gwałtowny wzrost liczby aborcji chemicznej. Do 2017 r. zastosowało tę pigułkę kilkadziesiąt milionów kobiet na całym świecie. Preparat Mifepriston nie tylko uśmierca nowe życie ludzkie na pierwszym etapie jego rozwoju, ale w niektórych przypadkach jest także niebezpieczny dla życia i zdrowia kobiet. W 2017 r. oficjalne dane mówiły o 29 zgonach matek w różnych krajach, wywołanych przyjęciem pigułki RU-486. Analiza aspektów etycznych stosowania pigułki „miesiąc później” upoważnia do sformułowania czterech następujących wniosków.

Po pierwsze, proces globalizacji oraz gwałtowny rozwój Internetu i mediów elektronicznych sprawiają, że coraz trudniej tworzyć prawo w obrębie konkretnych państw, które mogłoby skutecznie bronić godności życia ludzkiego od poczęcia do naturalnej śmierci. Nowe media elektroniczne umożliwiają w pewien sposób wolną aborcję chemiczną dla wszystkich w wymiarze globalnym - także poza systemami ochrony zdrowia poszczególnych krajów (por. Webo3). Nie bez znaczenia jest też działalność Funduszu Ludnościowego ONZ, promującego aborcję medyczną, oraz potężnych międzynarodowych koncernów farmaceutycznych, oferujących wiele nowoczesnych preparatów chemicznych, które umożliwiaja „bezpieczną, szybką i sprawną” eliminacje życia ludzkiego na pierwszym etapie jego rozwoju (por. Web-04). W dobie Internetu prawie wszystko staje się dostępne dla każdego - niestety, także farmakologiczne preparaty aborcyjne. Dlatego nie wolno dzisiaj zapominać o kwestii podstawowej - rzetelnej wiedzy, argumentacji filozoficznej, budzeniu wrażliwości moralnej, poszerzaniu 
świadomości etycznej i kształtowaniu sumień.

Po drugie, w ocenie moralnej stosowania preparatu RU-486 kluczowe znaczenie ma niszczenie poczętego życia. Aborcja jest niezależnie od tego, w jaki sposób zostaje dokonana - świadomym i bezpośrednim unicestwieniem istoty ludzkiej w początkowym stadium jej życia, obejmującym okres między poczęciem a narodzeniem. Natura i stopień zła moralnego aborcji nie zmieniają się w zależności od stosowanych metod - tak w przypadku aborcji chirurgicznej, jak i w jej formie chemicznej mamy do czynienia ze zniszczeniem życia ludzkiego na pierwszym etapie jego rozwoju. Stosowanie preparatów aborcji medycznej neguje prawo embrionu do życia, które jest podstawowym prawem człowieka. Przysługuje ono osobie ludzkiej od momentu poczęcia aż po naturalną śmierć. Prawo do życia zostało potwierdzone przez Powszechną Deklarację Praw Człowieka ONZ z 1948 r. W tym dokumencie czytamy, że prawo do życia jest prawem naturalnym, nienaruszalnym, niezbywalnym i powszechnym.

Po trzecie, w sporze dotyczacym aborcji chemicznej kluczowe znaczenie ma określenie momentu, w którym faktycznie rozpoczyna się życie człowieka. Dopiero podkreślenie człowieczeństwa ludzkiego embrionu ukazuje we właściwym świetle moralne zło stosowania tabletki RU-486. Dla chrześcijańskiej etyki personalistycznej, która odwołuje się także do faktów empirycznych, potwierdzonych przez nauki przyrodnicze, kryterium człowieczeństwa jest moment poczęcia. Nowy człowiek powstaje w momencie połączenia się dwóch komórek rozrodczych: męskiej i żeńskiej. Z tą chwilą rozpoczyna się życie nowej istoty ludzkiej. Owszem, ludzki embrion przechodzi w swoim rozwoju różne stadia, zachowuje jednak ciągłość i genetyczną tożsamość. Dlatego człowiek jest istotą ludzką od momentu poczęcia. Nigdy nie wolno traktować ludzkiego embrionu - według zasady personalistycznej - jako środka do celu, ale zawsze jako cel sam w sobie.
Po czwarte, legalizacja pigułki RU-486 w wielu krajach potwierdza bardzo wyraźnie umacniający się obecnie prymat technologii nad etyką. Zdumiewa tempo dokonujących się zmian w tym obszarze. Przykładem głębokiej rewolucji obyczajowej może być chociażby Australia. W tym kraju przez wiele lat tabletka „miesiąc później” nie była dostępna w aptekach. W 1996 r. została nawet uchwalona specjalna ustawa federalna, która zakazywała sprzedaży tego preparatu aborcyjnego na terenie całego kraju. Jednak w 2006 r. pigułka RU-486 została dopuszczona do obrotu. Co więcej, w 2013 r. - zgodnie z zaleceniami Funduszu Ludnościowego ONZ - tabletka „miesiąc później” została wpisana przez władze rządowe w Canberrze na listę leków refundowanych. Australia stanowi egzemplifikację dokonujących się na naszych oczach głębokich zmian w sferze moralnej, których przejawem jest m.in. globalna plaga aborcji chemicznej i chirurgicznej.

\section{Bibliografia}

Cavoni C., Sacchini D., 2008, La storia vera della pillola abortiva RU-486, Cantagalli, Siena.

Colombo R., 2017, Ma che cosa è l'aborto se non spezzare la vita, Avvenire, nr 77, 2.

Del Re G. M., 2017, "L'aborto è omicidio. Docente sospeso a Lovanio, Avvenire, nr 77, 13.

Flamigni C., Melega C., 2010, RU-486. Non tutte le streghe sono state bruciate, L'Asino d'Oro, Torino.

Gormally L., 2004, Diritti dell'embrione, w: Leone S., Privitera S. (red.), Nuovo Dizionario di Bioetica, Città Nuova Editrice - Edizioni ISB dell'Istituto Siciliano di Bioetica, Roma - Arcireale, 314-319.

Kobyliński A., 2007, Czy embrion jest osobą? Spór o sztuczne zapłodnienie we Wtoszech, Studia Ecologiae et Bioethicae, nr 5, 157-172.

Kobyliński A., 2015, Wpływ wspótczesnej rewolucji antropologicznej na rozumienie matżeństwa $i$ rodziny, Studia Theologica Varsaviensia, nr 53/1, $11-36$.

Lejeune C., 2005, Życie jest szczęściem. Jérôme Lejeune - mój ojciec, Wydawnictwo eSPe, Kraków.

Lo Sapio L., 2017, Bioetica cattolica e bioetica laica nell'era di Papa Francesco. Cosa è cambiato?, Edizioni Utet, Torino. 
Machinek M., 2005, Embrion ludzki, w: Muszala A. (red.), Encyklopedia bioetyki. Personalizm chrześcijański. Głos Kościoła, Polskie Wydawnictwo Encyklopedyczne, Radom, 136-144.

Morresi A., Roccella E., 2010, La favola dell'aborto facile. Miti e realtà della pillola $R U$-486, Franco Angeli Edizioni, Milano.

Otowicz R., 1998, Etyka życia. Bioetyczny i teologiczny kontekst problematyki życia poczętego, Wydawnictwo WAM, Kraków.

Puccetti R., 2008, L'uomo indesiderato. Dalla pillola di pincus alla $R U-486$, Società Editrice Fiorentina, Firenze.

Sedgh G., Bearak J., 2016, Abortion incidence between 1990 and 2014: global, regional, and subregional levels and trends, Lancet, nr 388/10041, 258-267. Sgreccia E., 1996, Manuale di bioetica. Fondamenti ed etica biomedica, Vita e Pensiero, Milano.

Ślipko T., 2009, Bioetyka. Najważniejsze problemy, Wydawnictwo PETRUS, Kraków.
(Web-01) Respinti M., Una firma per bloccare la tassa che finanzia l'aborto, http://www.lanuovabq. it/it/articoli-una-firma-per-bloccare-la-tassa-che -finanzia-laborto-15659.htm, dostęp: 15.05.2017.

(Web-02) Scandroglio T., L'Onu promuove la pillola killer dell'auto-aborto, http://www.lanuovabq.it/ it/articoli-lonu-promuove-la-pillola-killer-dellauto-aborto-17845.htm, dostęp: 15.05.2017.

(Web-03) Scandroglio T., L'aborto è on line con le pillole ammazza bimbi, http://www.lanuovabq.it/ it/articoli-laborto-e-on-linecon-le-pilloleammazza-bimbi-11041.htm, dostęp: 15.05.2017.

(Web-04) Frigerio B., Il vero problema non è la RU-486 ma l'aborto, http://www.lanuovabq.it/it/ articoli-il-vero-problema-non-e-la-ru486-ma-l-aborto-1947o.htm, dostęp: 15.05.2017.

\title{
Safe abortion? Ethical aspects of the use of the abortion pill RU-486
}

\begin{abstract}
The article focuses on ethical aspects of chemical abortion, also known as pharmaceutical or medical abortion. Chemical abortion is typically done using two drugs. The first is mifepristone, also known as RU-486, and the second is misoprostol. The drugs are taken orally over three days, although the abortion itself may take much longer to complete. Mifepristone is an antiprogestin: it works by blocking the pregnancy hormone progesterone. Progesterone is "pro-gestation", as the name suggests, and makes the nutrients in the uterine lining available to the newly-conceived fetus as it arrives from the fallopian tube. A chemical abortion causes a serious reaction in a woman's body in order to cause it to interrupt and expel the pregnancy. Global phenomenon of medical abortion opens today a new stage of the public dispute about the beginning of human life and the recognition of the human embryo as the human being from the very moment of the conception.
\end{abstract}

\section{Key words}

ethics, bioethics, abortion pill RU-486, chemical abortion, medical abortion, human embryo, demographic policy, emergency contraception 